\title{
TENDENCJE NA RYNKU MIĘSA WIEPRZOWEGO NA ŚWIECIE I W POLSCE W LATACH 2000-2016
}

\author{
Stanisław Stańko*, Aneta Mikuła** \\ *Katedra Ekonomiki Rolnictwa i Międzynarodowych Stosunków Gospodarczych \\ Szkoły Głównej Gospodarstwa Wiejskiego w Warszawie \\ Kierownik Katedry: dr hab. Joanna Kisielińska, profesor SGGW \\ **Katedra Ekonomii i Polityki Gospodarczej Szkoły Głównej Gospodarstwa Wiejskiego w Warszawie \\ Kierownik Katedry: dr hab. Alina Daniłowska, profesor SGGW
}

\begin{abstract}
Słowa kluczowe: produkcja wieprzowiny, eksport, import, konsumpcja, ceny
Key words: pork meat production, exports, imports, consumption, price

S y n o p s i s. Opracowanie przedstawia zmiany na rynku wieprzowiny na świecie i w Polsce w latach 2000-2016. Analizowano zmiany u największych jej producentów i konsumentów, a także eksporterów i importerów. Do głównych światowych producentów wieprzowiny należą: Chiny, kraje UE, USA, Brazylia, Rosja i Wietnam, które w 2016 r. skupiały 88,2\% światowej produkcji. U głównych światowych producentów wieprzowiny (z wyjątkiem Chin) wzrost konsumpcji był wolniejszy niż produkcji, co spowodowało zwiększenie ich możliwości eksportowych. W latach 2000-2016 tempo wzrostu handlu międzynarodowego było szybsze niż produkcji, co skutkowało wzrostem udziału eksportu w zagospodarowaniu produkcji. Źródła światowego eksportu wieprzowiny charakteryzowały się znaczną i rosnącą koncentracją. W 2016 r. z krajów UE pochodziło 37,6\% eksportu, z USA 28,5\%, z Kanady 15,9\% i z Brazylii $10 \%$. (92\% ogółu eksportu). Światowy import wieprzowiny charakteryzował się znacznie większym rozproszeniem niż eksport. Ceny wieprzowiny wykazały tendencję wzrostową. W kraju występowała tendencja spadkowa w produkcji, a wzrostowa w konsumpcji, co spowodowało, że od 2008 r. Polska jest importerem netto wieprzowiny.
\end{abstract}

\section{WSTĘP}

Chów trzody chlewnej w Polsce i w wielu innych krajach jest ważną gałęzią produkcji rolniczej. Wynika to z udziału w strukturze produkcji towarowej rolnictwa czy też dominującego udziału wieprzowiny w konsumpcji mięsa. W latach 2000-2016 produkcja mięsa na świecie ogółem zwiększyła się o 42,7\%, w tym wieprzowiny o $35 \%$, wołowiny o prawie $21 \%$, a mięsa drobiowego o $80,5 \%{ }^{1}$. Pomimo różnej dynamiki produkcji, udział wieprzowiny w światowej produkcji dominował i wynosił w 2016 r. 42,4\%. W Polsce w badanych latach również nastąpił wzrost produkcji mięsa ogółem o 64,3\%, w tym wołowiny o 43,3\%, ale zmniejszyła się produkcja wieprzowiny o $0,7 \%$ i wzrosła 6,5 razy produkcja mięsa drobiowego. W wyniku takich zmian w Polsce w produkcji dominowało mięso z drobiu $(48,4 \%$, wzrost o 27,8 p.p. w porównaniu do 2000 r.), zmniejszył się udział wieprzowiny do 40,6\%

Obliczono na podstawie [USDA FAS 2001-2017]. 
(spadek o 26,6 p.p.) oraz wołowiny do 11\% (spadek o 1,2 p.p.). Pomimo zmniejszenia udziału w produkcji, mięso wieprzowe dominuje w konsumpcji w Polsce. Jego spożycie wynosiło w 2000 r. 39 kg na 1 mieszkańca, co dawało mu 59-procentowy udział w spożyciu mięsa ogółem. W 2016 r. spożycie wieprzowiny wynosiło 40,1 kg na 1 mieszkańca i spożycie to miało 54,4\% udziału w spożyciu mięsa ogółem w kraju [„,Rynek ...” 2017, s. 73].

Produkcja wieprzowiny w poszczególnych krajach w warunkach gospodarki rynkowej charakteryzuje się wahaniami pogłowia i produkcji, znanymi w teorii ekonomii pod pojęciem tzw. cykli świńskich. Wahania te zaliczane są do tzw. cykli specjalnych, mających własny mechanizm [Małkowski, Zawadzka 1995, s. 6]. Istotę mechanizmu cyklu świńskiego wyjaśniono teoretycznie na podstawie modelu pajęczyny (cobweb) [Ezekiel 1938, s. 255-280, Ritson 1977, s. 135, Tomek, Robinsom 2001, s. 169, Ferris 2005].

Współcześnie, pomimo postępującej koncentracji i specjalizacji, rozwoju pionowej i poziomej integracji, w rozwoju pogłowia i produkcji wieprzowiny widoczne są wahania noszące znamiona cyklu świńskiego. Jest to wyraźnie widoczne na rynkach regionalnych, krajowych i międzynarodowych [Zawadzka 2016, Stępień 2015]. Natomiast na rynku światowym (globalnym) wahania cykliczne mogą się wzajemnie znosić.

Rosnąca konsumpcja wieprzowiny przy spadającym pogłowiu trzody w Polsce spowodowała konieczność uzupełnienia krajowej podaży wieprzowiną z importu. Polska przez wiele lat była eksporterem netto mięsa wieprzowego i jego przetworów, a od 2008 r. stała się importerem netto [Stańko, Mikuła 2016]. Rosnący import mięsa i żywych zwierząt w Polsce jest jednym z głównych czynników wpływających na produkcję. Stwarza to konieczność oceny prawidłowości występujących na rynkach zagranicznych, które decydują o sytuacji na rynku i możliwościach rozwoju produkcji w kraju.

\section{CEL OPRACOWANIA, MATERIAŁ, METODY ANALIZY}

Celem opracowania było określenie dominujących kierunków zmian w kształtowaniu się produkcji, konsumpcji i obrotów handlowych na rynku mięsa wieprzowego na świecie u głównych jego producentów, konsumentów, eksporterów i importerów. Do głównych producentów wieprzowiny zaliczono te kraje, które w ostatnich 5 latach (2012-2016) wytwarzały co najmniej 2 mln ton mięsa rocznie. Były to: Chiny, kraje Unii Europejskiej (UE), USA, Brazylia, Rosja, i Wietnam. Udział tych krajów w światowej produkcji w 2016 r. wynosił $88,2 \%{ }^{2}$. Kraje te były także największymi konsumentami wieprzowiny. Ich udział w konsumpcji w 2016 r. wynosił 85,3\% ${ }^{3}$. Kierunki zmian w eksporcie określono dla głównych światowych producentów wieprzowiny, a także Kanady, która w ostatnich kilkunastu latach eksportowała rocznie ponad $1 \mathrm{mln}$ ton wieprzowiny. Natomiast tendencje w imporcie określono dla głównych producentów i tych krajów, które importowały rocznie powyżej $0,2 \mathrm{mln}$ ton wieprzowiny. Przedmiotem badań była produkcja mięsa wieprzowego w wadze poubojowej w latach 2000-2016. Siedemnastoletni okres pozwolił wyodrębnić główne kierunki zmian, które określono na podstawie modeli tendencji, a do pomiaru dynamiki badanych kategorii (produkcji, konsumpcji, eksportu, importu i cen) wykorzystano indeksy statystyczne [Jóźwiak, Pogórski 1998] oraz średnią stopę zmian, przy której obliczaniu uwzględniono wszystkie wyrazy szeregu chronologicznego [Timofiejuk 1990].

Obliczono na podstawie [USDA FAS, 2001-2017].

Obliczono na podstawie [USDA FAS, 2001-2017]. 


\section{WYNIKI BADAŃ}

Tendencje na rynkach zagranicznych wieprzowiny mają ważne znaczenie dla rynku w Polsce. Wynika to z powiązań handlowych, obejmujących import i eksport żywca (żywych zwierząt) oraz mięsa i jego przetworów. W 2016 r. import żywca do Polski wyniósł prawie 6,3 mln szt., a eksport 54,8 tys. szt. [,Rynek...”2017, s. 25-26]. Z kolei import mięsa i przetworów w tym roku wyniósł 649,5 tys. t, a eksport 614,1 tys. $\mathrm{t}$ (przy rocznym uboju trzody w kraju w wysokości 15,9 mln szt. i rocznej produkcji mięsa wynoszącej 1879 tys. $t$ [,Rynek...”2017, s. 23, 14 i 74].

\section{TENDENCJE W PRODUKCJI I KONSUMPCJI WIEPRZOWINY}

W latach 2000-2016 produkcja wieprzowiny na świecie zwiększała się przeciętnie o 1848 tys. t rocznie, tj. w tempie 1,9\%. Dynamika produkcji była zróżnicowana (rys. 1.). U głównych producentów wieprzowiny produkcja rosła przeciętnie o 1654 tys. t rocznie, tj. w tempie 1,9\%, a w pozostałych krajach-mniejszych producentach średnioroczny wzrost produkcji wynosił 187,8 tys. $\mathrm{t}(1,7 \%)$. Niższe tempo wzrostu produkcji u mniejszych producentów spowodowało nieznaczne zmniejszenie ich udziału w światowej produkcji z 12,9\% w 2000 r. do $11,5 \%$ w 2016 r. Tempo wzrostu produkcji u największych producentów wieprzowiny było zróżnicowane. U największego producenta wieprzowiny, którym były Chiny, roczny wzrost produkcji wynosił 910,2 tys. t, tj. 1,9\% rocznie. W krajach UE produkcja wieprzowiny zwiększała się średniorocznie o 310,8 tys. t, tj. o 1,5\%, a w USA o 155,7 tys. t, tj. o 1,6\%. Takie tempo wzrostu produkcji wieprzowiny w tych krajach (Chiny, kraje UE i USA) spowodowało nieznaczne zmniejszenie ich udziału w światowej produkcji, z 81,8\% w 2000 r. do 79,8\% w 2016 r. , w tym Chin z 49,5\% do 48,2\%, krajów UE z $21,5 \%$ do $21,3 \%$ oraz USA z 10,8\% do 10,3\%. Należy jednak dodać, że z krajów tych pochodziło 4/5 światowej produkcji. Szybciej niż na świecie produkcja wieprzowiny zwiększała się w takich krajach, jak: Wietnam, Brazylia i Rosja. W Wietnamie rocznie produkcja wieprzowiny rosła o 104,2 tys. $\mathrm{t}$, tj. w tempie $6,1 \%$, w Brazylii o 90,4 tys. t, tj. w tempie 3,2\%, a w Rosji roczny wzrost wynosił 73,6 tys. t, tj. 3,6\%. Spowodowało to, że Wietnam, Brazylia i Rosja zwiększyły swój udział w światowej produkcji: Wietnam z $1,2 \%$ do 2,4\%, Brazylia z 2,2\% do 3,4\% i Rosja z 1,8\% do 2,6\%. Ogółem te trzy kraje zwiększyły swój udział w światowej produkcji z 5,2\% w 2000 r. do 8,4\% w 2016 r.

Przedstawione wyniki rozważań pozwalają stwierdzić, że światowa produkcja wieprzowiny jest skoncentrowana geograficznie. W 2000 r. sześciu jej największych producentów (Chiny, kraje UE, USA, Brazylia, Rosja, i Wietnam) wytwarzało 87\% światowej produkcji, a w 2016 r. było to $88,2 \%$.

W badanych latach nastąpiły także zmiany w konsumpcji wieprzowiny. Ogółem konsumpcja wieprzowiny charakteryzowała się tendencją wzrostową (rys. 2.). Tempo zmian było zróżnicowane w poszczególnych krajach. U największych światowych producentów wieprzowiny roczny wzrost produkcji był większy niż konsumpcji o 159 tys. t, co zwiększało możliwości eksportowe tych krajów. W największej skali możliwości eksportowe wieprzowiny zwiększyły się w USA, w których roczny wzrost produkcji był większy od rocznego przyrostu konsumpcji o 132,2 tys. t. Podobne kierunki zmian wystąpiły także w krajach UE, w których wzrost produkcji był wyższy od przyrostu konsumpcji o 100,3 tys. t rocznie oraz w Brazylii o 16,4 tys. t. Także niewielkie nadwyżki wystąpiły w Rosji 


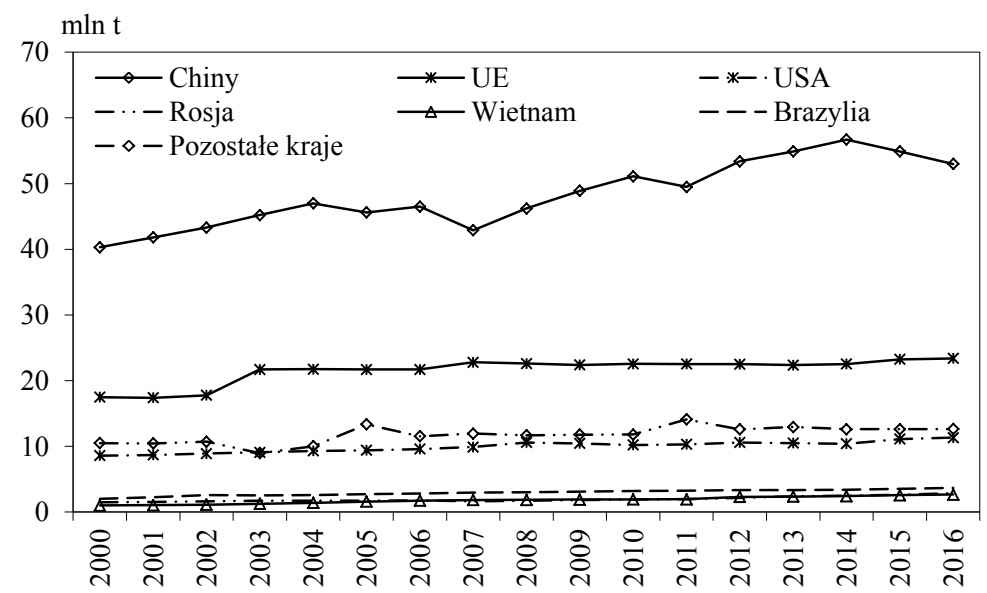

Rysunek 1. Produkcja wieprzowiny u głównych jej producentów na świecie w latach 2000-2016 Źródło: opracowanie na podstawie [USDA FAS 2001-2017].

(1,1 tys. t) i w Wietnamie (1,3 tys. t). Tylko u największego producenta wieprzowiny na świecie, w Chinach, przyrost konsumpcji był większy od wzrostu produkcji o 100,3 tys. t. W wyniku tego zwiększał się import mięsa do tego kraju. Rosnący import uwidocznił się szczególnie w latach 2010-2016.

U mniejszych producentów wieprzowiny tempo wzrostu konsumpcji $(2,8 \%)$ było wyższe od tempa przyrostu produkcji $(1,7 \%)$, co skutkowało wzrostem importu. Ogółem struktura geograficzna konsumpcji niewiele różniła się od struktury produkcji wieprzowiny, a zmiany w latach 2000-2016 były niewielkie. W 2000 r. udział trzech największych

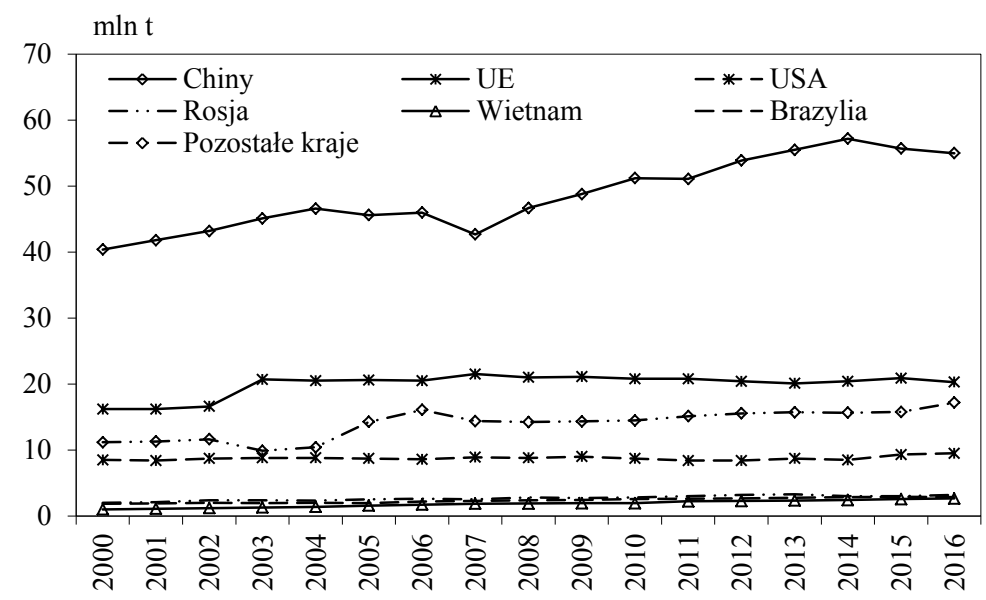

Rysunek 2. Konsumpcja wieprzowiny u głównych jej producentów na świecie w latach 2000-2016 Źródło: jak na rysunku 1. 
światowych producentów wieprzowiny (Chiny, USA, kraje UE) w jej konsumpcji wynosił 80,3\% (a w produkcji 81,8\%) i zmniejszył się do 77,4\% w 2016 r. (w produkcji wynosił $79,4 \%$ ). Natomiast udział w konsumpcji sześciu największych producentów wieprzowiny (wcześniej wymienione oraz Rosja, Wietnam i Brazylia) w 2000 r. wynosił 86,3\% (a w produkcji 87\%) i zmniejszył się do 85,3\% w 2016 r. (w produkcji wynosił 88,2\%).

\section{TENDENCJE W ŚWIATOWYM HANDLU WIEPRZOWINĄ}

W badanych latach (2000-2016) handel międzynarodowy wieprzowiną charakteryzował się tendencją wzrostową. Tempo wzrostu eksportu było szybsze $(5,2 \%$ rocznie) niż produkcji (1,9\% rocznie), co powodowało zwiększenie udziału eksportu w zagospodarowaniu produkcji. W 2000 r. poprzez eksport na rynkach światowych zagospodarowane było 4,2\% produkcji, a w 2016 r. - 7,6\%. Powiązanie rynków krajowych z rynkami światowymi poprzez obroty handlowe wieprzowiną było bardzo zróżnicowane. Spośród największych światowych producentów znaczącymi eksporterami wieprzowiny były: USA, kraje UE, Brazylia, a także Kanada, którą można zaliczyć do średnich producentów, natomiast niewielkie ilości mięsa na rynki światowe sprzedawały takie kraje, jak: Chiny, Rosja, Wietnam (rys. 3.).

Najszybciej w latach 2000-2016 rósł eksport wieprzowiny z USA, przeciętnie w roku wzrastał o 128,5 tys. $\mathrm{t}$ (w tempie 9,3\% rocznie). W wyniku tego udział eksportu $\mathrm{w}$ zagospodarowaniu produkcji w tym kraju zwiększył się z 6,6\% w 2000 r. do $21 \%$ w 2016 r. Eksport wieprzowiny z krajów UE zwiększał się przeciętnie o 97,3 tys. t rocznie, tj. w tempie 5,4\%, a udział eksportu w zagospodarowaniu produkcji w krajach niebędących członkami UE ${ }^{4}$ wzrósł z 8,4\% w 2000 r. do 13,3\% w 2016 r. Kanada zwiększała rocznie eksport wieprzowiny o 34,1 tys. $t$ (w tempie $3,4 \%$ rocznie), co spowodowało wzrost udziału produkcji zagospodarowywanej na rynkach światowych z 40,2\% w 2000 r. do 67,5\% w 2016 r.

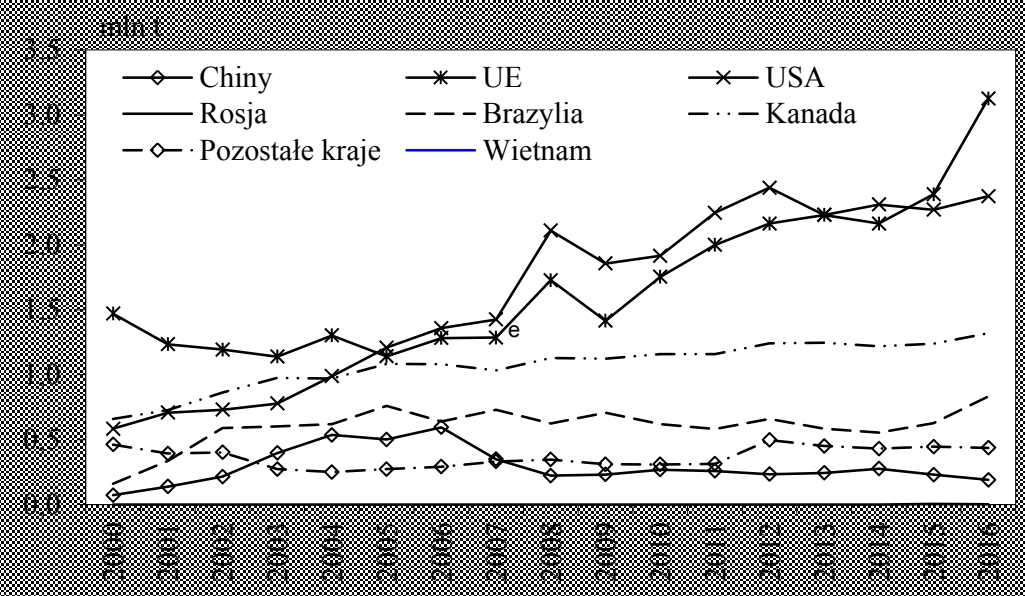

Rysunek 3. Eksport wieprzowiny przez głównych jej producentów i eksporterów na świecie w latach 2000-2016

Źródło: jak na rysunku 1.

4 Często określa się je jako „kraje trzecie”. 
Brazylia zwiększała eksport o 16,3 tys. t rocznie (w tempie 4\%), co spowodowało wzrost udziału eksportu w produkcji z 8,1\% w 2000 r. do 22,5\% w 2016 r. ${ }^{5}$. Wywóz wieprzowiny z USA, krajów UE, Brazylii i Kanady dominował w światowym eksporcie. W 2000 r. $\mathrm{z}$ tych krajów pochodziło 84,2\% światowego eksportu wieprzowiny, w tym z krajów UE 43,1\%, z USA 17,1\%, z Kanady 19,3\% i z Brazylii - 4,7\%, a w 2016 r. odpowiednio: z UE - 37,6\%, z USA - 28,5\%, z Kanady - 15,9\% i z Brazylii - 10\%. Oznacza to, że w 2016 r. z wymienionych krajów pochodziło $92 \%$ światowego eksportu wieprzowiny. Eksport wieprzowiny z pozostałych dużych jej producentów (Chiny, Rosja, Wietnam) był znikomy (w granicach 0,01-0,4\% produkcji). Eksport z Chin w latach 2000-2005 charakteryzował się tendencją wzrostową (wzrost roczny o 93,3 tys. t) i w tym okresie wzrósł prawie 8-krotnie. Od 2006 roku charakteryzował się tendencją spadkową przeciętnie o 21,3 tys. t rocznie, tj. w tempie $6,1 \%$. W wyniku takich zmian udział eksportu w zagospodarowaniu produkcji w Chinach wynosił 0,2\% w 2000 r., 1,3\% - w 2006 r. i 0,4\% - w 2016 r. Eksport wieprzowiny z pozostałych krajów zwiększał się przeciętnie o 5,7 tys. t, tj. w tempie 1,6\% rocznie, natomiast dużych producentów i eksporterów (USA, kraje UE, Brazylia i Kanada) roczny wzrost eksportu wynosił 276,2 tys. t (rósł rocznie o 5,9\%). W wyniku takich tendencji w światowym eksporcie wieprzowiny malał udział mniejszych producentów (zmniejszenie z 15,8\% w 2000 r. do 8\% w 2016 r.), a dominowali duzi jej producenci.

Przedstawione kierunki zmian w eksporcie wieprzowiny pozwalają stwierdzić, że źródła podaży wieprzowiny na rynkach światowych charakteryzowały się znaczną i rosnącą koncentracją. Podaż wieprzowiny na rynkach światowych pochodziła głównie z USA, krajów UE, Kanady i Brazylii. Udział podaży z tych krajów w 2016 r. stanowił $92 \%$ światowej podaży wieprzowiny.

Eksport wieprzowiny na rynki światowe odbywał się głównie z tych krajów, które charakteryzowały się znaczną i postępującą koncentracją produkcji chowu trzody. Świadczy o tym dominujący udział pogłowia w większych stadach i przeciętna liczba trzody w przeliczeniu na gospodarstwo. W USA w 2012 r. na jedno gospodarstwo prowadzące chów przypadało 970 szt. trzody (w 2000 r. było to 685 szt.), w gospodarstwach z pogłowiem liczącym ponad 5000 szt. znajdowało się 62\% pogłowia ogółem [Stępień 2015, s. 144]. W UE głównymi eksporterami na rynki światowe, tj. poza UE, były takie kraje, jak: Niemcy, Dania, Hiszpania, Holandia i Francja. Przeciętne pogłowie trzody w gospodarstwach rolnych w Danii w 2013 r. wynosiło 3123 szt. (w 2005 r. było to 1500 szt.), w Holandii odpowiednio: 2172 szt. i 1176 szt., we Francji: 725 szt. w 2013 r. i 353 szt. W 2005 r., w Niemczech 572 szt. i 303 szt., w Hiszpanii 492 szt. i 197 szt. ${ }^{6}$. Jednocześnie poziom koncentracji produkcji był wysoki, o czym świadczy udział pogłowia w większych stadach. W 2010 r. w stadach 1000 i więcej szt. w Danii było 95,5\% pogłowia, w Holandii 88,2\%, we Francji - 76,8\%, w Niemczech 65,6\%, w Hiszpanii 81,7\% [Stańko 2013, s. 136]. Z tych krajów realizowano 83\% eksportu do krajów trzecich [Zawadzka 2016, s. 63]. Udział Polski w eksporcie UE na rynki krajów trzecich wynosił 3\%.W Kanadzie w 2016 r. przeciętne stado trzody w gospodarstwie wynosiło 1882 szt. $^{7}$ (w 2006 r. było to 1308 szt.) [Brisson 2014]. Z kolei w Brazylii przeciętna wielkość stada trzody wynosiła 800 szt. [Stępień 2015, s. 174].

Produkcja trzody w Polsce w porównaniu do największych eksporterów wieprzowiny była bardzo rozdrobniona. Przeciętne stado w 2013 r. liczyło 40 szt. (w 2005 r. było to 25 szt.), a w stadach 1000 i więcej szt. znajdowało się 25,3\% pogłowia [Stańko 2013,

Obliczenia własne na podstawie [USDA FAS, 2001-2017].

Dla 2005 r. [EC 2012], dla 2013 r. obliczenia własne na podstawie [Eurostat 2014].

Obliczenia własne na podstawie [Canadian... 2017]. 
s. 136]. Oznacza to, że poziom koncentracji produkcji trzody chlewnej w Polsce był niski w porównaniu do głównych eksporterów wieprzowiny z UE i eksporterów światowych (USA, Kanada, Brazylia).

Zmiany importu wieprzowiny przez największych jej producentów charakteryzowały się różnokierunkowymi tendencjami (rys. 4.). Tendencją wzrostową charakteryzował się import przez największego światowego producenta wieprzowiny - Chiny. W latach 2000-2009 import zwiększał się przeciętnie o 31,5 tys. $\mathrm{t}$ rocznie, tj. w tempie $11,1 \%$, a w następnym okresie (lata 2011-2016) tempo wzrostu zwiększyło się do 22,4\% rocznie. W tym okresie przeciętnie w roku wzrost importu wynosił 224,5 tys. t. To spowodowało, że udział Chin w światowym imporcie zwiększył się z 4,3\% w 2000 r. do 27,4\% w 2016 r. W Rosji import wieprzowiny w latach 2000-2012 zwiększał się przeciętnie o 38,2 tys. t, tj. w tempie 5\% rocznie. W latach 2013-2016 import zmniejszał się w szybkim tempie przeciętnie w ciągu roku o 167 tys. t. W pozostałych krajach największych producentów (kraje UE, USA, Wietnam, Brazylia) import wieprzowiny charakteryzował się tendencją spadkową. Tempo spadku było zróżnicowane. W krajach UE import zmniejszał się o 2 tys. $t$ rocznie, tj. w tempie 4,3\%, w USA roczny spadek importu wynosił 2,1 tys. t, tj. $0,5 \%$, w Brazylii roczny import zmniejszał się o 0,4 tys. t, tj. o 5,1\%, a w Wietnamie odpowiednio: o 0,4 tys. $t$ (1,7\%). Należy jednak zaznaczyć, że import wieprzowiny przez kraje UE, Brazylię i Wietnam był niewielki i kształtował się na poziomie do $0,2 \%$ jej spożycia.

Do największych importerów wieprzowiny oprócz Chin można zaliczyć także Japonię, Meksyk, Koreę Południową, Hong Kong i Kanadę ${ }^{8}$ Import wieprzowiny przez Japonię zwiększał się przeciętnie o 13,9 tys. t rocznie, tj. w tempie 1,2\%, Meksyk o 44,4 tys. t, tj. w tempie 7,9\%, w Korei Południowej roczny wzrost importu wynosił 28 tys. t, tj. rósł w tempie $9 \%$, do Hong Kongu 11,1 tys. t, tj. 3,4\%, a do Kanady - 10,4 tys. t, tj. rósł w tempie $7,2 \%$. odmienna dynamika i skala importu spowodowały zmiany w strukturze importerów. Udział Chin w światowym imporcie wieprzowiny zwiększył się z 4,3\%

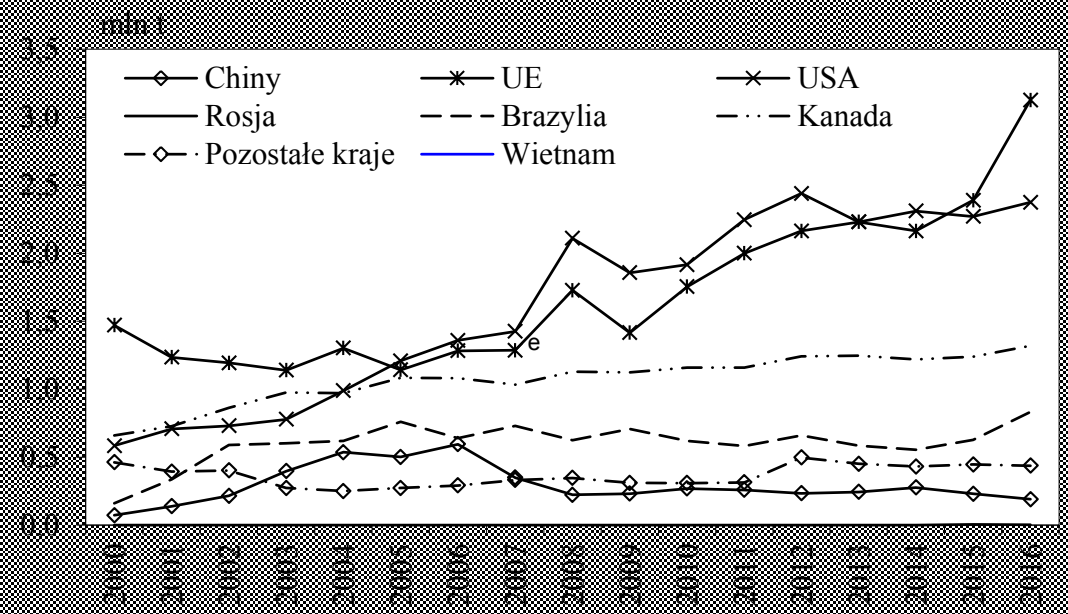

Rysunek 4. Import wieprzowiny przez głównych jej producentów i importerów na świecie w latach 2000-2016 Źródło: jak na rysunku 1.

Do tej grupy zaliczono kraje, które w ostatnich 5 latach importowały rocznie 200 i więcej tys. ton. 
w 2000 r. do 27,4\% w 2016, Japonii zmniejszył się z 31\% w 2000 r. do 17,1\% w 2016 r., a Meksyku wzrósł z 8,6\% w 2000 r. do 12,8\% w 2016 r. Ogółem udział trzech największych światowych importerów wieprzowiny (Chiny, Japonia i Meksyk) zwiększył się z 43,9\% w 2000 r. do 57,3\% w 2016 r. Z kolei importerzy, których można nazwać średnimi ${ }^{9}$ (Korea Płd., Hong Kong, Rosja, USA, Kanada), zmniejszyli udział w światowym imporcie z 45,1\% w 2000 r. do 26,4\% w 2016 r. Udział pozostałych krajów w imporcie wieprzowiny w badanych latach zwiększył się z 11\% w 2000 r. do 16,3\% w 2016 r.

Z oceny skali importu wieprzowiny przez poszczególne kraje wynika, że charakteryzuje się on znacznie większym rozproszeniem niż eksport tego mięsa. W 2016 r. udział trzech największych importerów w światowym imporcie wynosił 57,3\% (w przypadku eksporterów udział ten wynosił 82\%), z kolei udział pięciu największych eksporterów w światowym eksporcie wynosił 94,3\%, a importerów 71,2\%.

\section{ZMIANY PRODUKCJI, KONSUMPCJI I OBROTÓW HANDLU ZAGRANICZNEGO WIEPRZOWINĄ W POLSCE W LATACH 2000-2016}

Produkcja wieprzowiny w Polsce w latach 2000-2016 charakteryzowała się tendencją spadkową, wokół której obserwowano wahania cykliczne (rys. 5.). Spadek produkcji w badanym okresie wynosił przeciętnie 12,6 tys. t rocznie, tj. 0,7\%. Duży spadek produkcji nastąpił w latach 2008-2009. W 2008 r. produkcja obniżyła się o 203 tys. t (o 9,7\%) w porównaniu do 2007 r. i w 2009 była niższa o dalsze 173 tys. t (o 9,2\%) w porównaniu do 2008 r. Tak duże obniżenie produkcji wynikało z redukcji pogłowia trzody w gospodarstwach. W tych latach pogłowie trzody chlewnej obniżyło się o prawie 3,4 mln szt. ${ }^{10}$ [GUS 2009, 2010]. Spadek pogłowia trzody w tym okresie był znacznie szybszy niż produkcji mięsa. Wynikało to ze wzrostu importu żywych zwierząt. W $2007 \mathrm{r}$. import żywych zwierząt wyniósł 401,7 tys. szt., w 2008 r. - 1124,6 tys. szt. (wzrost o 180\%), i w 2009 r. - 1997,6 tys. szt. (wzrost o 77,6 \%) [,Rynek...” nr 40, s. 16]. Spadek pogłowia trzody chlewnej w Polsce

tys. $\mathrm{t}$

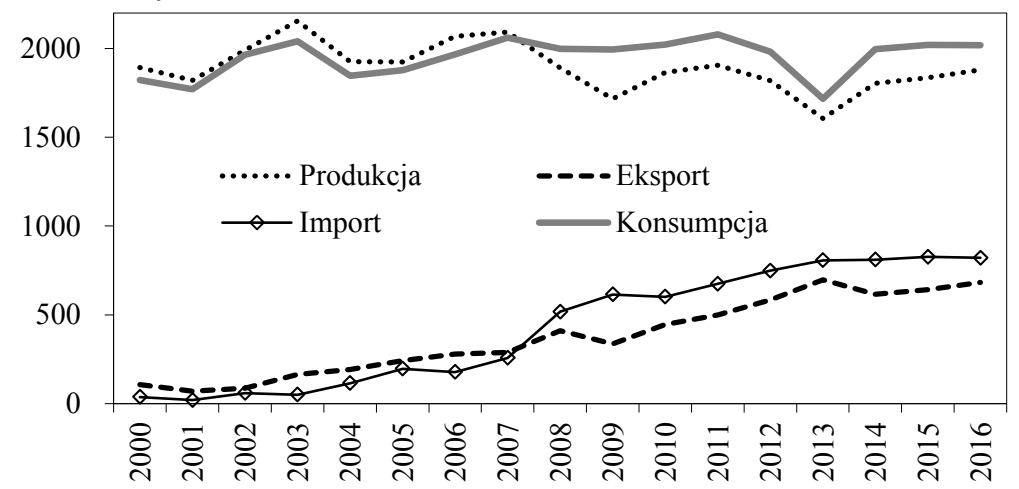

Rysunek 5. Produkcja, konsumpcja, eksport i import wieprzowiny w Polsce latach 2000-2016 Źródło: opracowanie własne na podstawie [GUS 2006-2016, „Rynek...” 2000-2017, „Handel...” 2002-2017].

\footnotetext{
9 Za takie uznano te kraje, które importowały rocznie więcej niż 200 tys. $\mathrm{t}$ rocznie i mniej niż $1 \mathrm{mln} \mathrm{t}$.

10 Według stanu na koniec roku.
} 
wynikał z rezygnacji z produkcji przez gospodarstwa prowadzące chów w małej skali [Stańko, Mikuła 2016, s. 34].

Konsumpcja wieprzowiny w badanych latach charakteryzowała się niewielką tendencją wzrostową, przeciętnie w roku rosła o 7,6 tys. $\mathrm{t}$ (rocznie o 0,4\%). W wyniku takiej tendencji wzrosło spożycie wieprzowiny w przeliczeniu na mieszkańca z $39 \mathrm{~kg} \mathrm{w} 2000 \mathrm{r}$. do 40,1 kg w 2016 r. [„Rynek...” nr 52, s. 72]. W wyniku takich zmian konsumpcja wieprzowiny w Polsce od 2008 r. była wyższa od produkcji. Oznacza to konieczność uzupełnienia podaży krajowej importem mięsa i jego przetworów oraz importem żywca.

Polska przez wiele lat była eksporterem netto mięsa wieprzowego i jego przetworów. Dynamika obrotów handlu zagranicznego wieprzowiną i jej przetworami oraz żywcem w badanych latach była zróżnicowana. Obroty handlowe przed integracją Polski z UE były względnie ustabilizowane. W latach 2000-2002 import wynosił średnio w roku 39 tys. t, a eksport 88 tys. t [Stańko, Mikuła 2016]. Przyspieszenie obrotów handlowych z UE rozpoczęło się po podpisaniu porozumienia o liberalizacji handlu. Można je było zaobserwować w latach 2003-2013. Eksport zwiększał się przeciętnie o 49 tys. t rocznie, $\mathrm{tj}$. w tempie $13,6 \%$ rocznie, a import w tym okresie wzrastał o 81,5 tys. $\mathrm{t}$, tj. o 25,8\% rocznie. Niewielkie tempo wzrostu konsumpcji wieprzowiny w kraju przy tendencji spadkowej produkcji oraz szybszy wzrost importu niż eksportu spowodowały, że od 2008 r. Polska stała się importerem netto wieprzowiny. Spowolnienie tempa wzrostu eksportu i importu występowało w latach 2014-2016. W porównaniu do 2013 r. eksport charakteryzował się niewielką tendencją spadkową o 2 tys. $t$ rocznie (tj. w tempie $0,3 \%$ ), a import wzrastał o 5,6 tys. $\mathrm{t}, \mathrm{tj}$. w tempie $0,7 \%$ rocznie (rys. 4 .).

Tendencja spadkowa w produkcji wieprzowiny zaznacza się w średnim okresie. Wynika to z rosnących wymagań w zakresie ochrony środowiska, rosnących problemów $\mathrm{z}$ chorobą $\mathrm{ASF}^{11}$, a także rezygnacji $\mathrm{z}$ chowu trzody $\mathrm{w}$ gospodarstwach $\mathrm{z}$ mniejszymi stadami. Takie tendencje na rynku wieprzowiny w naszym kraju skutkować będą ograniczaniem produkcji. Te kierunki zmian oznaczają, że Polska pozostanie importerem netto mięsa wieprzowego w średnim okresie. Niezbędny import netto na uzupełnienie podaży krajowej można oszacować na około 200 tys. ton rocznie.

\section{TENDENCJE W KSZTAŁTOWANIU SIĘ CEN WIEPRZOWINY}

Ceny wieprzowiny determinowane są przez różne czynniki. Do podstawowych można zaliczyć:

- działanie prawa podaży i popytu,

- biologiczno-techniczny charakter produkcji,

- powiązania rynku żywca wieprzowego z rynkiem produktów spożywczych (mięsa i jego przetworów),

- powiązania rynku krajowego z rynkami zagranicznymi i światowymi,

- powiązania z cenami na rynkach zagranicznych i światowych,

- czynniki makroekonomiczne wpływające na rolnictwo, przemysł przetwórczy (np. tempo wzrostu dochodów konsumentów, kursy walut, koniunktura w branży przetwórstwa mięsa),

- ceny innych produktów mięsnych i ich przetworów,

- inne czynniki [Hamulczuk i in. 2012].

${ }_{11} \mathrm{ASF}-($ African Swine Fever) afrykański pomór świń jest to choroba wirusowa. 


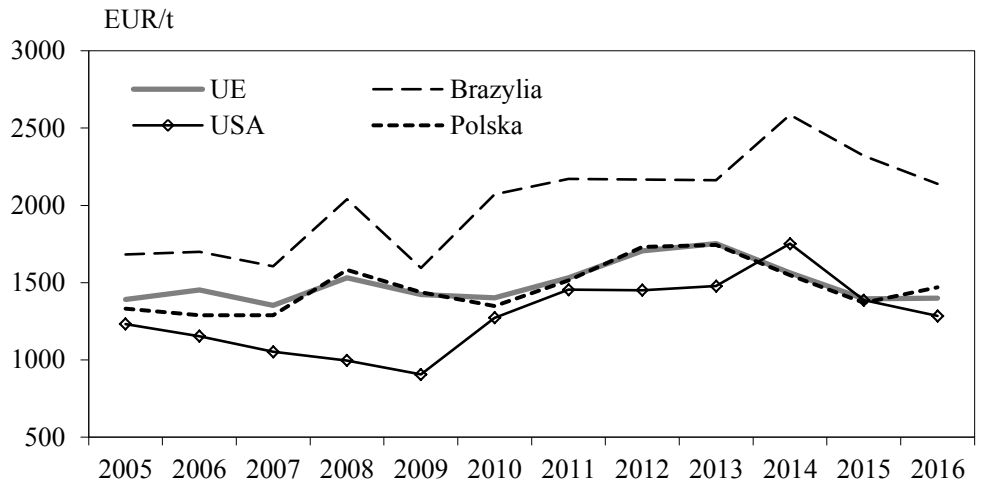

Rysunek 6. Ceny wieprzowiny na rynkach światowych (Brazylii, USA), UE i w Polsce latach 2005-2016

Źródło: opracowano na podstawie [EC 2016, tablica 9.26] dla cen UE i światowych oraz obliczenia szacunkowe własne dla cen w Polsce.

Duże znaczenie w kształtowaniu cen wieprzowiny na rynkach światowych mają także takie czynniki, jak: znaki i marki towarowe, marki handlowe, promocja towarów, międzynarodowe sieci handlowe, a także struktura towarowa handlu.

Kierunki zmian cen wieprzowiny na różnych rynkach w latach 2005-2016 przedstawiono na rysunku $6 .^{12}$.

Ceny wieprzowiny w latach 2005-2016 na różnych rynkach (krajowym, UE czy światowym) wykazywały tendencję wzrostową. W badanych latach najszybciej zwiększały się ceny wieprzowiny z Brazylii (3,5\% rocznie), wolniejsze tempo wzrostu wystąpiło w przypadku wieprzowiny w USA (3,2\% rocznie), najwolniej zwiększały się ceny wieprzowiny w UE $(0,7 \%$ rocznie). W Polsce w tych latach ceny wieprzowiny rosły rocznie o $1,4 \%$. Szybsze tempo wzrostu cen wieprzowiny z USA niż cen UE spowodowało zmniejszenie różnic $\mathrm{w}$ poziomie cen między tymi rynkami. W 2005 r. ceny wieprzowiny z UE były wyższe niż z USA o 12,8\%, a w 2016 r. różnica ta zmniejszyła się do 9\%.

Szybsze tempo wzrostu cen w Polsce niż w UE spowodowało zmiany ich relacji. W 2005 r. ceny w Polsce były niższe niż w UE o 4,2\%, a w 2016 r. wyższe o 5\%.

Najszybciej w badanych latach wzrastały ceny wieprzowiny z Brazylii, co zwiększyło różnice w poziomie cen. W 2005 r. ceny w UE były o 17,4\% niższe niż w Brazylii, a w 2016 r. różnica ta wynosiła 34,5\%.

Z projekcji Komisji Europejskiej wynika, że w najbliższych latach konsumpcja wieprzowiny w UE będzie praktycznie ustabilizowana, 31,5 kg per capita w 2016 r. i $31,8 \mathrm{~kg}$ w 2026 r. W krajach UE-15 konsumpcja może się obniżyć z 31,6 kg per capita w 2016 r. do 31,2 kg w 2026 r., a w krajach UE-13 może nieznacznie wzrosnąć (z 32,9 kg per capita w 2016 r. do 34,5 kg per capita w 2026 r.). W podobnym tempie jak wzrost konsumpcji może się zwiększyć produkcja, co oznacza, że kraje UE dysponować będą nadwyżkami produkcji wieprzowiny, które powinny być zagospodarowane na rynkach krajów poza UE [EC 2016, s. 78]. Nadwyżki rynkowe w UE i konieczność ich zagospodarowania poza UE wpływać będą ograniczająco na wzrost cen, z powodu niższych cen światowych

2 Z powodu braku wiarygodnych danych o cenach w latach 2000-2004, przedstawiono informacje o cenach w latach 2005-2016. 
dużych eksporterów zwłaszcza USA i Kanady. Z projekcji Komisji Europejskiej wynika, że w kształtowaniu się cen wieprzowiny do 2026 r. może być kontynuowana nieznaczna tendencja wzrostowa, wokół której występować będą wahania cyklicznie. W 2020 r. ceny wieprzowiny mogą wynosić 1617 EUR/t, a w 2026 r. 1672 EUR/t [EC 2016, s. 78]. Podobne ceny mogą także występować w Polsce.

\section{PODSUMOWANIE}

W opracowaniu przedstawiono zmiany w produkcji, konsumpcji i handlu zagranicznym wieprzowiną na świecie, u głównych jej producentów, konsumentów, eksporterów i importerów w latach 2000-2016. Produkcja wieprzowiny na świecie charakteryzowała się tendencją wzrostową. Przeciętne tempo wzrostu produkcji wynosiło 1,9\%. Wzrost produkcji u największych jej producentów (z wyjątkiem Chin) był większy niż konsumpcji, co spowodowało zwiększenie możliwości eksportowych. W wyniku tego wzrosły światowe obroty handlowe wieprzowiną. W największej skali możliwości eksportowe wieprzowiny zwiększyły się w USA, krajach UE, a także w Brazylii i Kanadzie. Z tych krajów w 2016 r. pochodziło $92 \%$ światowego eksportu wieprzowiny (w 2000 r. było to $84,3 \%$ ). Podaż wieprzowiny na rynkach światowych charakteryzowała się znaczącą i rosnącą koncentracją i pochodziła głównie z krajów o dużej i rosnącej koncentracji w produkcji trzody chlewnej.

Największymi importerami wieprzowiny w ostatnich latach były: Chiny, Japonia, Meksyk, Korea Południowa, Hong Kong i Kanada. Na kraje te przypadało w 2016 r. 68\% światowego importu wieprzowiny (w 2000 r. było to 49,4\%). W porównaniu do podaży, import wieprzowiny charakteryzował się znacznie większym rozproszeniem.

W Polsce w produkcji wieprzowiny zaobserwowano tendencję spadkową, a w konsumpcji - wzrostową. W wyniku tego Polska od 2008 r. jest importerem netto mięsa wieprzowego. Rozdrobnienie produkcji trzody i niewielki postęp w jej koncentracji powodują, że udział kraju w handlu na rynkach światowych jest niski. Przewidywane niewielkie wzrosty cen światowych wieprzowiny powodują, że głównym czynnikiem determinującym opłacalność chowu trzody będzie wykorzystanie efektów skali produkcji. Powolne przemiany strukturalne w produkcji trzody chlewnej w Polsce, rosnące wymogi dotyczące ochrony środowiska i dobrostanu, rezygnacja z chowu trzody przez mniejszych producentów mogą ograniczać wzrost produkcji. W wyniku takich uwarunkowań Polska w średnim okresie pozostanie importerem netto wieprzowiny.

\section{LITERATURA}

Brisson Yan, 2014: The changing face of the Canadian hog industry, Analytical Paper, No 5, Statistics Canada.

Canadian Pork Council, Canadian Hog Farms, http://www.cpc-ccp.com/canadian_hog_farms.php, dostęp: 30.09.2017.

EC (European Commission), 2012: Agriculture in the European Union. Statistical and Economic Information. Report 2012, tab. 3.5.3.10. Changing structure of pig farms, by Member State and Candidate Countries.

EC (European Commission), 2016: EU Agricultural Outlook. Prospects for the EU agricultural markets and income 2016-2026.

Eurostat, 2014: Agriculture $>$ Agriculture $>$ Data $>$ Main tables 2014. Agricultural holding with livestock (hold Pigs) and Number of pigs.

Ezekiel Michael, 1938: The Cobweb Theorem, "The Quarterly Journal of Economics", vol. 53, no. 2, s. 255-280. 
Ferris John N., 2005: Agricultural Prices and Commodity Market Analysis, Michigan State University Press, s. 99-120.

GUS, 2006-2016: Roczniki satystyczne rolnictwa, Warszawa.

GUS, 2009: Zwierzęta gospodarskie w 2008 r., Informacje i opracowania statystyczne, Warszawa.

GUS, 2010: Zwierzęta gospodarskie w 2009 r., Informacje i opracowania statystyczne, Warszawa.

Hamulczuk Mariusz, Stanisław Gędek, Cezary Klimkowski, Stanisław Stańko, 2012: Prognozowanie cen surowców rolnych na podstawie zależności przyczynowych, Program Wieloletni 2011-2014, IERiGŻ-PIB, Warszawa.

„Handel zagraniczny produktami rolno-spożywczymi. Stan i perspektywy. Analizy rynkowe”, 20022017: IERiGŻ, ARR, MRiRW, Warszawa, nr 16-45.

Jóźwiak Janina, Jarosław Podgórski, 1998: Statystyka od podstaw, PWE, Warszawa.

Małkowski Jan, Danuta Zawadzka, 1995: Wahania w produkcji trzody chlewnej w Polsce i innych krajach, Komunikaty, Raporty, Ekspertyzy nr 389, IERiGŻ, Warszawa.

Ritson Christopher, 1977: Agricultural Economics. Principles and Policy, Collins. 8 Grafton Street London W1.

„Rynek Mięsa. Stan i Perspektywy”, 2000-2017: IERiGŻ, ARR, MRiRW, nr 19-52.

Stańko Stanisław, 2013: Zmiany i projekcje rozwoju na podstawowych rynkach rolnych $w$ Polsce, Wydawnictwo SGGW, Warszawa.

Stańko Stanisław, Aneta Mikuła, 2016: Tendencje w produkcji, zużyciu krajowym $i$ handlu zagranicznym wieprzowina, wołowina i mięsem drobiowym w Polsce w latach 2000-2015, „Roczniki Naukowe Ekonomii Rolnictwa i Rozwoju Obszarów Wiejskich”, z. 2, t. 103, s. 31-40.

Stępień Sebastian, 2015: Cykl świński w świetle zmian na globalnym rynku żywca wieprzowego, Wydawnictwo Naukowe PWN, Warszawa.

Timofiejuk Igor, 1990: Tablice średniego tempa wzrostu wedtug metody R, GUS, Zakład Badań Statystycznych, Warszawa.

Tomek William, G., Kenneth L. Robinson, 2001: Kreowanie cen artykułów rolnych, Wydawnictwo Naukowe PWN, Warszawa

USDA FAS (United States Department of Agriculture Foreign Agricultural Service), 2001-2016: Livestock and Poultry. World Markets and Trade.

Zawadzka Danuta, 2016: Rynek wieprzowiny, [w] Sytuacja na światowych rynkach mięsa i produktów mleczarskich oraz jej wpływ na rynek krajowy i możliwości jego rozwoju, red. Stanisław Stańko, Monografie Programu Wieloletniego nr 31, IERiGŻ-PIB, Warszawa, s. 58-70.

Stanisław Stańko, Aneta Mikuła

TENDENCIES IN THE WORLD PORK MARKET AND IN POLAND IN THE YEARS 2000-2016

\section{Summary}

The study presents changes in the world pork market and in Poland in the years 2000-2016. Changes in the main producers and consumers, as well as exporters and importers were presented. The major global producers of pork are China, the EU, USA, Brazil, Russia and Vietnam, which in 2016 produced $88.2 \%$ of total world production. In the world's major pork producers (except China), consumption growth was slower than production growth, which increased their export capacity. In the years 2000-2016, the growth rate of international trade was higher than production, what led to an increase in the share of exports in production. Global pork exports is characterized by a large and growing concentration rate. In 2016, 37.6\% of exports came from the EU, 28.5\% from the USA, 15.9\% from Canada and 10\% from Brazil (total $92 \%$ of exports). World pork imports were characterized by a much greater dispersion than exports. Pork prices have shown an upward trend. In Poland there was a downward trend in pork production and growth in consumption, which caused that since 2008 Poland is a net importer of pork. Poland will remain a net importer of pork in the medium term.

Adres do korespondencji:

Prof. dr hab. Stanisław Stańko, dr inż. Aneta Mikuła Szkoła Główna Gospodarstwa Wiejskiego w Warszawie Wydział Nauk Ekonomicznych ul. Nowoursynowska 166, 02-787 Warszawa e-mail: stanislaw_stanko@sggw.pl, aneta_mikula@sggw.pl 